DOI: http://doi.org/10.21698/simi.2017.0035

\title{
INTERDEPENDENCE BETWEEN TOTAL ORGANIC CARBON CONTENT AND HEATING VALUE OF SEWAGE SLUDGE SAMPLES
}

\author{
Agnes Serbanescu, Mona Barbu, Ileana Nicolescu, Elena Bucur
}

National Research and Development Institute for Industrial Ecology - ECOIND, 71-73 Drumu Podu Dambovitei Street, code 060652, Bucharest, Romania,poluare.aer@incdecoind.ro

\begin{abstract}
Sewage sludge from urban wastewater treatment plants come from different stages of wastewater treatment and are considered as waste, falling under the waste regulations. In order to reduce the negative environmental impacts, the removal of sewage sludge on landfill is considered as the last waste management option.

One of the sludge management alternatives is to recover energy from the sewage sludge by incineration in waste incinerators or co-combustion in cement or thermal power plants.

The use of sewage sludge as a source of renewable energy is an ecologically and economically efficient option, both in the EU and Romania sludge management strategy.

Total organic carbon is a key environmental indicator for soil, sludge and sediment and a parameter for characterizing sludge for energy recovery.

The paper presents the methodology for total organic carbon determination from acidified sludge samples by dry combustion, in an oxygen atmosphere using FlashEA 1112 Series Analyser.

From the experimental laboratory researches the following aspects were highlighted: the interdependence between the total organic carbon content and the heating value of sludge samples, an important factor for energy recovery/elimination by incineration, co-combustion and utilization as secondary raw materials in cement plants.
\end{abstract}

Keywords: co-combustion, heating value, incineration, sewage sludge, total organic carbon

\section{Introduction}

The modernization of existing municipal wastewater treatment plants or the construction of new ones leads to a substantial increase in the amount of sewage sludge to be managed. Sludges from urban waste water treatment plants come from different stages of sewage treatment and are considered as waste falling under the waste legislation. Removal of sludge in a landfill is considered as the last sludge management option to reduce adverse environmental impacts (Arama \& Kim 2016). One of the sludge management alternatives is energy recovery from sludge. The use of sludge from sewage treatment plants as a source of renewable energy is an option indicated to be both ecologically and economically efficient, both in the EU and Romania sludge management strategy.

A greater emphasis was put on energy recovery from sludge incineration, so at the EU 15 level, the amount of sludge incinerated increased from 1.5 Mt D.S./year in 


\section{INTERNATIONAL SYMPOSIUM "THE ENVIRONMENT AND THE INDUSTRY", SIMI 2017, PROCEEDINGS BOOK}

1995 to $3.1 \mathrm{Mt}$ in 2010 (an increase of $106.7 \%$ ) with an estimated increase in 2020, to 3.6 Mt D.S./year (Neamt \& Ionel 2013).

Through the research-development activity and implementation of high technology in recovery renewable energy resources in Germany, energy recovery through incineration of sewage sludge increased significantly, from $9 \%$ in 1991 to $53.2 \%$ in 2010 (an increase of $491 \%$ ) of the total sludge produced, with a humidity of $60 \%$ D.S. (Federal Institute of Ecology UBA 2011).

Sludge mono-incineration plants, in combined cycles, have been tested and developed in Germany beginning with 2005 at the Technical University of Braunschweig (Vockrodt 2004), as well as in the "HUBER - sludge2energy" technology (HUBER TECHNOLOGY).

The sewage sludge is mainly composed of wastewater, organic and inorganic suspensions. The factors influencing the characteristics of the sewage sludges are: the source and characteristics of wastewater (municipal and / or industrial); sludge removing as primary, secondary and tertiary sludge; aerobic or anaerobic stabilization; whether or not there are dehydration installations; addition or not of dehydrating additives (lime, polyelectrolytes) (Vockrodt 2004).

Sewage dehydrated sludge $(25 \%-40 \%$ dry substance) or dried (over $85 \%$ dry substance) can be incinerated in municipal waste incinerators, in municipal sewage sludge incineration plants or coincinerated in cement kilns, or co-incinerated in thermal power plants with lignite (Vockrodt 2004).

In order to estimate the available heat in sewage sludge is necessary to know the net calorific value of the sewage sludge, which is given by the organic substances contained therein. For the characterization of sludge for energy recovery purpose, an important parameter is also the total organic carbon content.

The paper presents the methodology for total organic carbon content determination from acidified sludge samples by dry combustion, in an oxygen atmosphere using FlashEA 1112 Series Analyser, and the interdependence between the total organic carbon content and the net calorific value of sludge samples.

\section{Materials and Methods}

Materials

Between 2014-2016, a sample of dehydrated sludge from a municipal wastewater treatment plant, was monthly characterized.

In the lab the sludge samples were air-dried at ambient temperature to remove the moisture content. The dried samples were milled using the Retsch Vibratory Disc Mill RS 200 in order to obtain a laboratory sample with a grain size of less than $200 \mu \mathrm{m}$.

\section{Methods}

The characterization of the sewage sludge samples was done by laboratory determination of the most relevant parameters, using standardized methods.

Determination of moisture and ash content was performed by gravimetric methods according to SR EN 12880:2002 and SR EN 15169:2007.

To predict the potential use of municipal sludge as a fuel, the most relevant parameters to consider are the net calorific value and the total organic carbon content.

The gross calorific value was determined by a calorimetric method according to SR EN 15170: 2009, using the PARR 6200 calorimetric bomb. 


\section{INTERNATIONAL SYMPOSIUM "THE ENVIRONMENT AND THE INDUSTRY", SIMI 2017, PROCEEDINGS BOOK}

The net calorific value was calculated according to SR EN 15170:2009 standard, using the gross calorific value and the hydrogen content. The net calorific value represents the available energy to be converted to thermal and / or electrical energy from the sludge.

\section{Total Organic Carbon content determination}

Total organic carbon is a key indicator for the characterization of sludge for energy recovery. Organic carbon in sludge is found in different forms. Due to the diversity of organic carbon compounds, the global total organic carbon (TOC) indicator is used. Total organic carbon content in sewage sludge was determined by a chromatographic method using the Thermo Scientific FlashEA 1112 Elemental Analyser according to SR EN 15936: 2013 standard.

The FlashEA 1112 is based on the well-known Flash Dynamic Combustion method, which produces complete combustion of the sample within a high temperature reactor, followed by an accurate and precise determination of the elemental gases produced using a TCD thermal conductivity detector. The sample combustion temperature was $950^{\circ} \mathrm{C}$. Total carbon dioxide released during combustion is expressed as carbon percent.

For total organic carbon content determination in sewage sludge samples the analytical process starts with the elimination of all inorganic carbons in the form of carbon dioxide by the effect of acidification of the sample with a small volume of phosphoric acid in special container.

The liquid phase produced was dried at a temperature lower than $40{ }^{\circ} \mathrm{C}$, and the special container was then closed and loaded into the autosampler carousel, and analyzed.

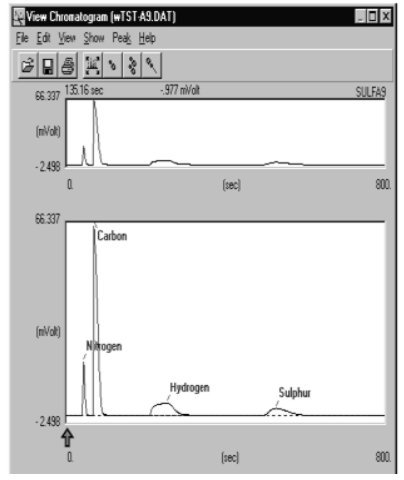

Figure 1. Chromatogram model for Thermo Scientific FlashEA 1112 Elemental Analyzer

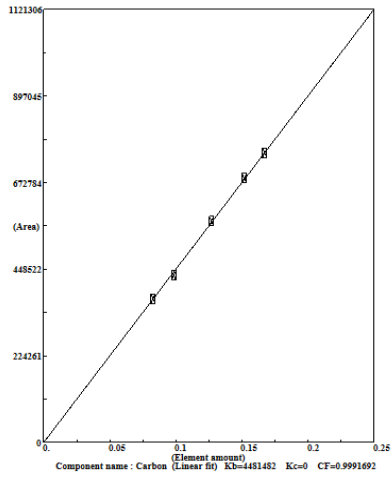

Figure 2. Calibration curve for carbon content

The sample quantity was chosen in such a way that the carbon dioxide released during combustion was in the analyzer working range.

For Thermo Scientific FlashEA 1112 elemental analyzer calibration, calcium carbonate reference material was used. In Fig. 1 it is presented a chromatogram, and 


\section{INTERNATIONAL SYMPOSIUM "THE ENVIRONMENT AND THE INDUSTRY", SIMI 2017, PROCEEDINGS BOOK}

in Fig. 2 a calibration curve for carbon. The regression coefficients for the calibration curves were about 0.999 .

In Table 1 presents the characteristics of the dehydrated sewage sludge samples analyzed during the period 2014-2016, in the form of minimum, average and maximum results and the used methods.

Table 1. Main chemical characteristics of the dehydrated sewage sludge sample analyzed during the period 2014-2016

\begin{tabular}{|c|c|c|c|c|c|}
\hline Parameters & U.M. & $\begin{array}{c}\text { Minimum } \\
\text { values }\end{array}$ & $\begin{array}{c}\text { Maximum } \\
\text { values }\end{array}$ & $\begin{array}{c}\text { Average } \\
\text { values }\end{array}$ & $\begin{array}{c}\text { Standardized } \\
\text { Methods }\end{array}$ \\
\hline \multicolumn{6}{|l|}{ Proximate analysis } \\
\hline Moisture content & $\%$ & 61.29 & 75.20 & 69.06 & SR EN 12880:2002 \\
\hline Dry substance & $\%$ & 24.8 & 38.71 & 30.94 & SR EN 12880:2002 \\
\hline $\operatorname{Ash}\left(550^{\circ} \mathrm{C}\right)$, ar & $\%$ & 11.19 & 26.08 & 16.21 & SR EN 15169:2007 \\
\hline Ash $\left(550^{\circ} \mathrm{C}\right), \mathrm{db}$ & $\%$ & 45.02 & 70.59 & 51.94 & SR EN 15169:2007 \\
\hline \multicolumn{6}{|l|}{ Ultimate analysis } \\
\hline Carbon, ar & $\%$ & 7.80 & 10.30 & 8.45 & SR EN 15407:2011 \\
\hline Carbon, $\mathrm{db}$ & $\%$ & 23.70 & 34.05 & 27.55 & SR EN 15407:2011 \\
\hline Hydrogen, ar & $\%$ & 0.56 & 1.54 & 1.05 & SR EN 15407:2011 \\
\hline Hydrogen, $\mathrm{db}$ & $\%$ & 1.88 & 4.48 & 3.43 & SR EN 15407:2011 \\
\hline Nitrogen, ar & $\%$ & 0.90 & 1.67 & 1.20 & SR EN 15407:2011 \\
\hline Nitrogen, $d b$ & $\%$ & 2.45 & 5.30 & 3.91 & SR EN 15407:2011 \\
\hline Sulfur, ar & $\%$ & 0.06 & 0.41 & 0.24 & SR EN 14582:2017 \\
\hline Sulfur, db & $\%$ & 0.17 & 1.42 & 0.78 & SR EN 14582:2017 \\
\hline TOC, ar & $\%$ & 6.57 & 10.19 & 7.73 & SR EN 15936:2013 \\
\hline TOC, $\mathrm{db}$ & $\%$ & 19.95 & 31.87 & 25.19 & SR EN 15936:2013 \\
\hline \multirow{2}{*}{ LHV, ar } & $\mathrm{kcal} / \mathrm{kg}$ & 217 & 633 & 375 & SR EN 15170:2009 \\
\hline & $\mathrm{MJ} / \mathrm{kg}$ & 0.91 & 2.65 & 1.57 & SR EN 15170:2009 \\
\hline \multirow{2}{*}{ LHV, $\mathrm{db}$} & $\mathrm{kcal} / \mathrm{kg}$ & 1700 & 3107 & 2458 & SR EN 15170:2009 \\
\hline & $\mathrm{MJ} / \mathrm{kg}$ & 7.12 & 13.01 & 10.29 & SR EN 15170:2009 \\
\hline
\end{tabular}

ar-as received; db-dry basis; TOC-total organic carbon; LHV-low heating value

\section{Results and Discussion}

The characteristics of the dehydrated sewage sludge samples analyzed (Table 1), are compared with the characteristics of a low grade coal (lignite) used in many combustion power plants in Romania. The results were compared at dry state. The analyzed sludge samples showed a dry matter content between $24.8 \%$ and $38.7 \%$, compared to lignit. The carbon content of sludge samples, as well as the net calorific value, is about $75 \%$ and $70 \%$ respectively of the lignite value. The hydrogen content of sludge samples is about $120 \%$ higher than in lignite.

The nitrogen content of sludge samples, an important indicator due to the formation of nitrogen oxides, is approx. 4 times higher than for lignite. Despite of the great content of sewage sludge in nitrogen, the conversion ratio of fuel $\mathrm{N}$ to $\mathrm{NO}_{x}$ is less than 5\%, and the total net emissions of $\mathrm{NO}_{x}$ are in very low levels (Fytili 2008 after Zhao 1994). The sulfur content of sludge samples is up to $50 \%$ lower than for lignite. From the data presented in Table 1, a close correlation is observed between the total organic carbon content and the low heating value of the analyzed sludge samples. In Table 2, the monthly results obtained for the total organic carbon content and the low heating value for the sewage sludge samples analyzed are presented. Fig. 3 shows the 


\section{INTERNATIONAL SYMPOSIUM "THE ENVIRONMENT AND THE INDUSTRY", SIMI 2017, PROCEEDINGS BOOK}

interdependence between the total organic carbon content and the low heating value of the analyzed sludge samples.

Table 2. Variation of total organic carbon content and low heating value for dehydrated sewage sludge samples

\begin{tabular}{c|ccc|c|ccc}
\hline $\begin{array}{c}\text { Crt. } \\
\text { No }\end{array}$ & $\begin{array}{c}\text { TOC db } \\
\%\end{array}$ & $\begin{array}{c}\text { LHV db } \\
\mathrm{kcal} / \mathrm{kg}\end{array}$ & $\begin{array}{c}\text { LHV db } \\
\mathrm{J} / \mathrm{g}\end{array}$ & $\begin{array}{c}\text { Crt. } \\
\text { No }\end{array}$ & $\begin{array}{c}\text { TOC db } \\
\%\end{array}$ & $\begin{array}{c}\text { LHV db } \\
\mathrm{kcal} / \mathrm{kg}\end{array}$ & $\begin{array}{c}\text { LHV db } \\
\mathrm{J} / \mathrm{g}\end{array}$ \\
\hline 1 & 20.13 & 1849 & 7.74 & 15 & 25.99 & 2630 & 11.01 \\
2 & 20.36 & 2098 & 8.78 & 16 & 26.51 & 2530 & 10.59 \\
3 & 20.40 & 1964 & 8.22 & 17 & 26.68 & 2686 & 11.25 \\
4 & 21.00 & 1991 & 8.34 & 18 & 26.79 & 2550 & 10.68 \\
5 & 21.40 & 2145 & 8.98 & 19 & 27.04 & 2629 & 11.01 \\
6 & 21.84 & 2236 & 9.36 & 20 & 27.10 & 2709 & 11.34 \\
7 & 21.94 & 2194 & 9.19 & 21 & 27.21 & 2775 & 11.62 \\
8 & 22.03 & 2293 & 9.60 & 22 & 27.21 & 2666 & 11.16 \\
9 & 23.71 & 2291 & 9.59 & 23 & 28.50 & 2690 & 11.26 \\
10 & 23.94 & 2253 & 9.43 & 24 & 28.98 & 2919 & 12.22 \\
11 & 24.49 & 2416 & 10.12 & 25 & 29.80 & 2869 & 12.01 \\
12 & 25.12 & 2544 & 10.65 & 26 & 30.34 & 2966 & 12.42 \\
13 & 25.22 & 2401 & 10.05 & 27 & 31.87 & 3107 & 13.01 \\
14 & 25.60 & 2581 & 10.81 & & & & \\
\hline
\end{tabular}

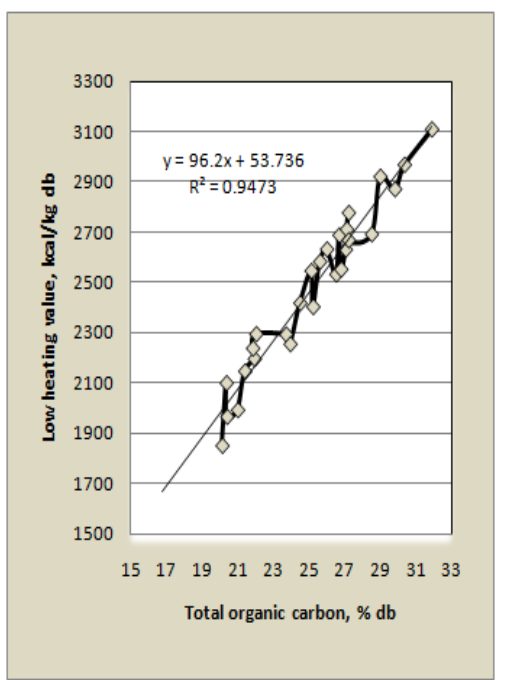

Figure 3. Interdependence between the total organic carbon content and the low heating value of the analyzed sludge samples

Between the total organic carbon content and the low heating value of the characterized sludge samples there is a linearity relation, described by the equation: $\mathrm{y}=96.2 * \mathrm{x}+53.736$

The degree of interdependence between the two variables, the total organic carbon and the low heating value, was evaluated using the Pearson (r) linear correlation coefficient. It is the ratio between the series covariance and the product of their 


\section{INTERNATIONAL SYMPOSIUM "THE ENVIRONMENT AND THE INDUSTRY", SIMI 2017, PROCEEDINGS BOOK}

standard deviations and presents values between -1 and 1 (ecuation no.1). The sign of the correlation coefficient indicates the direction of the association (inversely proportional to the sign - and directly proportional to the + sign) of the investigated variables (Facultatea de Medicina si Farmacie Iuliu Hategan Cluj Napoca 2017).

$$
r=\frac{\sum(x-\bar{x})(y-\bar{y})}{\sqrt{\sum(x-\bar{x})^{2} \sum(y-\bar{y})^{2}}}
$$

The value of the correlation coefficient $r$ for the presented curve is 0.973 . According to Colton's empirical rules (1974), a correlation coefficient greater than 0.75 (or less than -0.75 ) indicates a very good association or correlation of values.

The coefficient of determination $\mathrm{R}^{2}$ is the square of the correlation coefficient $\mathrm{r}$.

The value of the determination coefficient expresses an intensity of the linear relation between the two variables (total organic carbon and low heating value) or answers the question: how much of the variation of $\mathrm{Y}$ can be explained by the linear relationship with $\mathrm{X}$.

The value of the determination coefficient is 0.9473 . This value suggests a very good performance. In general, R2 value greater than 0.9 indicates a very satisfactory model performance.

\section{Conclusions}

Laboratory experimental researches were highlighted the interdependence between the total organic carbon content values of analysed sewage sludge samples and the low heating values, an important factor for energy recovery / final disposal through incineration / co-incineration processes and, last but not least, the use as secondary raw materials in cement factories from Romania.

The main advantages of the combustion or energy utilization of the sewage sludge are: electricity from sewage sludge saves fossil fuels and reduces fossil originated $\mathrm{CO} 2$ emissions, the amount of solid waste can be reduced, bacteriological load with pathogen agents does not present any more risks.

\section{References}

Arama, GM \& Kim, L 2016, 'Using waste hierarchy concept for optimizing the management of the waste disposal amount and implicitly of the possible ecological risk', International Symposium The Environment and The Industry, National Research and Development Institute for Industrial Ecology ECOIND, Bucharest, pp. 66-72.

Fytili, D \& Zabaniotou, A 2008, 'Utilization of sewage sludge in EU application of old and new methods', Renewable and Sustainable Energy Reviews, vol. 12, Issue 1, pp. 116-140.

http://www.huber.de.

http://www.huber.de/huber-report/ablage-berichte/sludge-treatment/ sludge2energya-way-to-energy-autarkic-operation-of-sewage-treatment-plants.html.

Neamt, I \& Ionel, I 2013, 'Environmental management of the sewage sludge: Case study - The wastewater treatment plant of Timisoara', Technical Gazette, vol. 3, pp. 435-439. 
SR EN 12880:2002, Characterisation of sludge's-Determination of dry residue and water content.

SR EN 15169:2007, Characterisation of waste-Determination of loss on ignition in waste, sludge and sediments.

SR EN 15170:2009, Characterisation of sludge's-Determination of calorific value.

SR EN 15936:2013, Sludge, treated bio-waste, soil and waste-Determination of total organic carbon (TOC) by dry combustion.

University of Medicine and Pharmacy Iuliu Hatieganu Cluj-Napoca 2017, Corelatii si regresii. Available from: https://www.info.umfcluj.ro/ro/did-ro/biostatro/mg1ro-ro/item/1050-curs-12-corelații-și-regresii.[10.07.2017].

Vockrodt, S, Leithner, R \& Kombi 2004, 'Combined Cycle with Integrated Sewage Sludge Combustion', MÜLL und ABFALL, vol. 12, pp. 590-594. 